\title{
Effect of food phenolic compounds on the activity of rat liver CYP2C subfamily enzymes evaluated by a newly validated method of high-performance liquid chromatography
}

\author{
Ramos, C. H.; Rolim, T. S.; Souza, T. P.; Moreira, D. L.;* Paumgartten, F. J. \\ R.; De-Oliveira, A. C. A. X.
}

Rev. Virtual Quim., 2019, 11 (5), 1444-1456. Data de publicação na Web: 23 de outubro de 2019

http://rvq.sbq.org.br

\begin{abstract}
Efeito de compostos fenólicos encontrados em alimentos sobre a atividade de enzimas da subfamília CYP2C do fígado de ratos avaliado por um novo método validado de cromatografia em fase líquida de alta eficiência
\end{abstract}

Resumo: Neste estudo, avaliamos os efeitos inibitórios de ácidos fenólicos (ácidos cafeico, ferúlico, $p$-cumárico e vanílico) e flavonoides (hesperidina, quercetina e rutina) sobre a atividade de CYP2C12/11 (ortologos da CYP2C9 humana). Um novo método de cromatografia em fase líquida de alta eficiência (HPLC-DAD) foi desenvolvido e validado para quantificar diclofenaco (DCF, substrato para CYP2C9) e 4'-hidroxidiclofenaco (4'-OH-DCF, produto da reação) em microssomos hepáticos de rato. Os efeitos fenólicos $(100 \mu \mathrm{M})$ e do fluconazol (controle positivo, $100 \mu \mathrm{M}$ ) sobre a hidroxilação do DCF (marcador para atividade de CYP2C9) foram testados em microssomos hepáticos de ratos Wistar fêmeas induzidos por tratamento com rifampicina. Quercetina, hesperidina e rutina apresentaram um efeito inibitório modesto (15-21 \% de inibição) sobre a atividade catalisada pela CYP2C no fígado de ratos, enquanto os ácidos fenólicos testados não exibiram qualquer efeito. Em conjunto, estes resultados indicaram que, nos níveis encontrados na dieta humana, é improvável que os fenólicos testados afetem o perfil de eliminação de fármacos e outros xenobióticos mediados por enzimas da subfamília CYP2C em ratos.

Palavras-chave: Citocromo P450, CYP2C, farmacocinética, interação medicamentosa, produtos naturais.

\begin{abstract}
In this study, we evaluated the inhibitory effects of phenolic acids (caffeic, ferulic, $p$-coumaric and vanillic acids) and flavonoids (hesperidin, quercetin and rutin) on the CYP2C11/12 (rat orthologs of human CYP2C9) activity. A new high performance liquid chromatographic (HPLC-DAD) method was developed and validated to measure diclofenac (DCF, CYP2C9 substrate) and 4' -hydroxy diclofenac (4'-OH-DCF, reaction product) in rat liver microsomes. The effect of phenolic compounds (PCs, $100 \mu \mathrm{M})$ and fluconazole (positive control, $100 \mu \mathrm{M}$ ) on the hydroxylation of diclofenac (CYP2C9 activity marker) were tested in rifampicin-induced rat liver microsomes. Quercetin, hesperidin and rutin exhibited a modest (15-21 \% inhibition) inhibitory effect on rat liver CYP2C-catalyzed activity, while no effect was noted with the tested phenolic acids. Overall, these findings indicated that, at levels found in the human diet, tested PCs are unlikely to inhibit CYP2C-mediated clearance of drugs and other xenobiotics in the rat.
\end{abstract}

Keywords: Cytochrome P450; CYP2C; pharmacokinetics; food-drug interaction; plant products.

\footnotetext{
* Fundação Oswaldo Cruz, Instituto de Tecnologia em Fármacos-ITF, Rua Sizenando Nabuco 100, CEP 21041-000, Manguinhos, Rio de Janeiro-RJ, Brasil.

Fundação Oswaldo Cruz, Laboratório de Toxicologia Ambiental-LTA, Av. Brasil 4036, Manguinhos, CEP 21040-361, Rio de Janeiro-RJ, Brasil.

Mdavyson.moreira@far.fiocruz.br

DOI: $\underline{10.21577 / 1984-6835.20190100}$
} 


\title{
Effect of food phenolic compounds on the activity of rat liver CYP2C subfamily enzymes evaluated by a newly validated method of high-performance liquid chromatography
}

\author{
Carlos H. Ramos, ${ }^{a}$ Thais S. Rolim, ${ }^{\text {a }}$ Thamyris P. de Souza, ${ }^{a}$ Davyson L. \\ Moreira, ${ }^{a, b, *}$ Francisco J. R. Paumgartten, ${ }^{a}$ Ana C. A. X. De-Oliveira ${ }^{a}$ \\ ${ }^{a}$ Fundação Oswaldo Cruz, Laboratório de Toxicologia Ambiental-LTA, Av. Brasil 4036, \\ Manguinhos, CEP 21040-361, Rio de Janeiro-RJ, Brasil.
}

${ }^{b}$ Fundação Oswaldo Cruz, Instituto de Tecnologia em Fármacos-ITF, Rua Sizenando Nabuco 100, Manguinhos, CEP 21041-000, Rio de Janeiro, RJ, Brasil.

\section{* davyson.moreira@far.fiocruz.br}

\section{Introduction}

\section{Experimental}

2.1. Inhibition of CYP2C mediated activity in rat liver microsomes

2.2. Diclofenac hydroxylation activity

2.3. High-Performance Liquid Chromatographic analysis coupled with Diode-Array Detector (HPLC-DAD)

2.4. Inhibition of CYP2C by phenolic acids and flavonoids

2.5. Statistical analysis

\section{Results and Discussion}

3.1. Quantification of the reaction product

3.2. Diclofenac hydroxylation activity assay

3.3. Inhibition of DCF hydroxylation (CYP2C) by phenolic acids and flavonoids

\section{Conclusion}

\section{Introduction}

Phenolic acids and flavonoids are plant phenolic compounds (PCs) present in variable amounts in tubers (sweet potato, burdock root), fruits (peach, apple and pear), vegetables (pumpkin), seeds (corn, beans), spices and herbs (thyme, sage, basil), wine, olive oil, chocolate, coffee and mate tea. ${ }^{1,2}$ Phenolic acids contain one or more free phenolic hydroxyl and carboxyl groups (mainly C6-C1 and C6-C3 skeleton) while flavonoids are plant (or fungus) secondary metabolites with a variable polyphenolic structure. ${ }^{3}$ Based on their flavan nucleus structure $\left(C_{6}-C_{3}-C_{6}\right.$ skeleton), flavonoids are classified as flavanones, isoflavanones, flavones, 
isoflavones, anthocyanidins, chalcones or

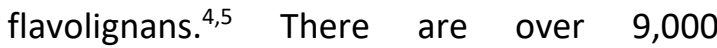
flavonoids described in the literature, and estimates of daily intake of flavonoids range from $20 \mathrm{mg}$ to $500 \mathrm{mg} .{ }^{5}$ A major contribution to daily intake of flavonoids comes from consumption of dietary supplements and food and beverages such as tea, red wine, apples, onions, tomatoes and others. ${ }^{5,6}$

Several plant-derived PCs exhibit strong antioxidant activity in in vitro and in vivo assays. Moreover, experimental evidence suggests that PCs possess a diversity of pharmacological activities of therapeutic interest, such as antibacterial, antiviral, antiinflammatory, hepatoprotective, immunomodulating and anti-carcinogenic effects. ${ }^{2,3,5,6,7,8}$

In fact, a number of epidemiology observational studies lend support to the notion that dietary PCs are beneficial to health. Diets containing high amounts of PCs, for instance, have been associated with decreased risks of lung, breast, prostate and colorectal cancers, tumors of other sites and other chronic-degenerative diseases. . $^{90,11,12,13}$

Although it is accepted that PCs are, as a rule, healthy food constituents, the hypothesis that some of these compounds might eventually change the clearance of drugs and other xenobiotics deserves to be analysed. This would not be surprising because several edible and medicinal plant products interfere with drug clearance and by doing so they, at times, dramatically modify therapeutic and adverse effects. A good example along this line is the strong inhibitory effect of grapefruit juice on CYP3A4-mediated drug clearance. ${ }^{14}$ Along the same line, CYP3A4- and 2B6- inducing effects of Saint John's wort (Hypericum perforatum), and of its constituent hyperforin, also illustrate that some herbs and medicinal plants markedly alter pharmacokinetics and clearance of other medications. ${ }^{15}$ Hyperforin is a ligand of pregnane $X$ nuclear receptor (PXR), a ligandactivated transcription factor, the activation of which promotes CYP3A4 transcription. ${ }^{15}$

The CYP2C isoforms are the second most abundant CYP enzymes in the liver where enzymes of this subfamily account for the oxidative metabolism of many routinely used drugs, including non-steroidal antiinflammatory agents such as diclofenac, ibuprofen and piroxicam. ${ }^{16,17}$

The objective of this study was to evaluate whether plant phenolic acids (caffeic, ferulic, $p$-coumaric and vanillic) and flavonoids (hesperidin, quercetin and rutin) inhibit CYP2C activity in rat liver microsomes. The conversion of diclofenac (DCF, a putative substrate for CYP2C9) into its primary oxidation metabolite (4'-hydroxy diclofenac, $4{ }^{\prime}$-OH-DCF) (Figure 1) by rat liver microsomes was used to study the effects of PCs on CYP2Ccatalyzed activity.

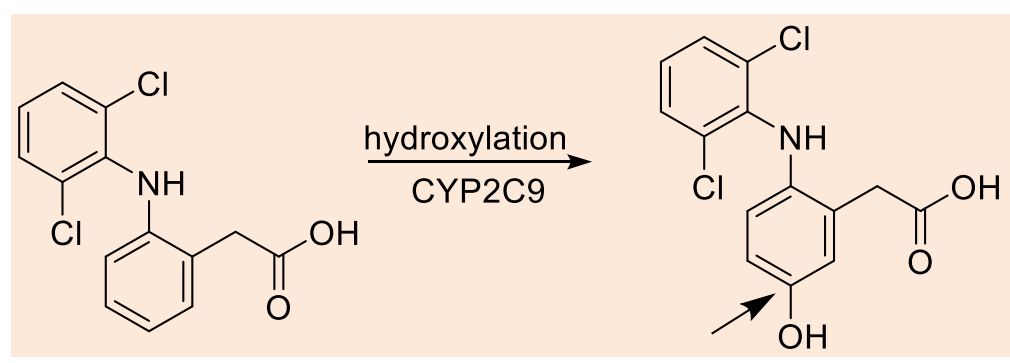

Figure 1. Hydroxylation of diclofenac (DCF) to 4'-hydroxy diclofenac (4'-OH-DCF) by CYP2C9. Arrow indicates the hydroxylation position 


\section{Experimental}

\subsection{Inhibition of CYP2C mediated activity in rat liver microsomes}

To investigate whether test compounds were capable of inhibiting CYP2C-mediated activity we used an in vitro rat liver microsomal fraction (LMF) assay. Aliquots of previously prepared rifampicin (RIF)-induced liver microsomes (300-450 mg/kg bwt/day x 5 days, po, female Wistar rats) stored in liquid nitrogen were used. ${ }^{18}$ The LMF was prepared essentially as described elsewhere (DeOliveira et al 1997). After thawing the frozen samples of RIF-induced LMF, the microsomal protein concentration was measured by a spectrophotometric method using Coomassie blue dye (Bradford method) and bovine serum albumin as standard. ${ }^{19,20}$ Total-protein concentration in the LMF was expressed as $\mathrm{mg}$ of protein per $\mathrm{mL}$. The experimental protocol was approved by the Ethics Committee on Animal Use of FIOCRUZ (2012, P-84/10-7).

The enzyme-mediated conversion of DCF into 4'-OH-DCF (catalyzed by CYP2C9 in humans) was used as a marker for CYP2C activity in the rat liver microsomal fraction (CYP2C11/12). To measure the accumulation of reaction product 4-hydroxy-diclofenac (4'$\mathrm{OH}-\mathrm{DCF}), \quad \mathrm{a}$ high-performance liquid chromatographic method was developed and validated.

\subsection{Diclofenac hydroxylation activity}

To standardize DCF hydroxylation assay with rat LMF, we evaluated how DCF hydroxylation activity varies over time for different protein concentrations $(0.25 ; 0.5 ; 1$ and $2 \mathrm{mg} / \mathrm{mL}$ ). The incubation of reaction mixture containing rat liver microsomal fraction, substrate (DCF), Tris buffer and cofactor solution took place for 10,20 or 30 min at $37{ }^{\circ} \mathrm{C}$ in a shaking water bath (Heto ${ }^{\circledR}$ ). $20 \mathrm{mM}$ Tris buffer solution (pH 7.5), $100 \mu \mathrm{M}$
DCF and a cofactor solution (0.5 mM $\beta$-NADP, $1.24 \mathrm{mM} \mathrm{G} 6 \mathrm{P}, 0.8 \mathrm{mM} \mathrm{MgCl}_{2}$ and $0.4 \mathrm{U} / \mathrm{mL}$ G6PD) were added to $1.5 \mathrm{~mL}$ eppendorf tubes for a final volume of $250 \mu \mathrm{L}$. A reaction mixture containing only the substrate (DCF), Tris buffer and the cofactor solution was preincubated for $3 \mathrm{~min}$. The hydroxylation reaction was then initiated by addition of rat LMF into the reaction mixture. After incubation for 10, 20 or $30 \mathrm{~min}$, reaction was stopped by adding acetonitrile and glacial acetic acid (94:6) solution. Tubes with the reaction mixture were subsequently centrifuged at $12,000 \times \mathrm{g}$ for $4 \mathrm{~min}$ to precipitate proteins. The supernatants were then removed to measure the amount of reaction product (4'-hydroxy diclofenac, 4'$\mathrm{OH}-\mathrm{DCF})$ formed. A reaction mixture not containing the microsomal fraction was the negative control (in the absence of the enzyme no 4'-OH-DCF was produced during incubation). Analysis of a set of curves of activity versus time for several concentrations of microsomal protein indicated that $1 \mathrm{mg} / \mathrm{mL}$ protein and 20 min reaction time were assay conditions ensuring a linear accumulation of reaction product over time. Fluconazole was chosen as positive control for CYP2C inhibition. $^{21}$

2.3. High-Performance Liquid Chromatographic analysis coupled with Diode-Array Detector (HPLC-DAD)

Determinations of DCF and 4'-OH-DCF in the supernatant of rat LMF reaction mixture were performed by using a Shimadzu Nexera ${ }^{\circledR}$ $X R$, equipped with LC-20AD binary pump, SIL20AF automatic injector, CTO-20A oven, DADUV-VIS SPD- 20MA detector and CBM-20A controller. Chromatograms were visualized through Labsolutions software (Shimadzu ${ }^{\circledR}$ ). The analytical method was developed in accordance with BD Bioscience ${ }^{\circledR}$ with a few adaptations. Validation parameters of selectivity, linearity, limits of identification and quantification were determined according to Normative Instruction DOQ- 
CGCRE 008 of INMETRO (2008). Different columns and mobile phases were tested to select the most appropriate conditions for 4'$\mathrm{OH}-\mathrm{DCF}$ (reaction product) and DCF (substrate) chromatographic analysis. The ultrapure water of mobile phase was from Milli-Q-MiliREP filtration system (Merck), methanol and acetonitrile were from Tedia (Brazil), and acetic acid from Sigma-Aldrich Co.

\subsection{Inhibition of CYP2C by phenolic acids and flavonoids}

Test compounds (caffeic, p-coumaric, ferulic and vanillic acids; rutin, quercetin and hesperidin flavonoids) and positive control (fluconazole) were all dissolved in $20 \mathrm{mM}$ Tris buffer solution ( $\mathrm{pH} 7.5$ ) and added in volumes and concentrations needed to attain a final concentration of $100 \mu \mathrm{M}$ in the reaction mixture.

\subsection{Statistical analysis}

Data were analyzed by ANOVA followed by the Bonferroni post-hoc multiple comparison test, when applicable. Differences were considered significant when $p<0.05$. Statistical analyses and graphics were done using Graphpad Prism5 ${ }^{\circledR}$.

\section{Results and Discussion}

\subsection{Quantification of the reaction product}

The chromatographic parameters for separation and quantification of 4'-OH-DCF (reaction product) by HPLC-DAD-UV or UPLCDAD-UV were determined by using a standard solution in water $(25 \mu \mathrm{g} / \mathrm{mL})$. Combinations of mobile and stationary phases conditions tested are shown on Table 1. Oven temperature $\left(50{ }^{\circ} \mathrm{C}\right)$ and injection volumes (ranging from 5 to $20 \mu \mathrm{L}$ ) were maintained constant in the tests.

The chromatographic condition with the best result in terms of capacity factor ( $k^{\prime} 4^{\prime}$ $\left.\mathrm{OH}-\mathrm{DCF}=5.8 ; \mathrm{k}^{\prime} \mathrm{DCF}=10.6\right)$, signal symmetry ( 1 for both compounds), retention time, $t R$, (4'-OH-DCF 4.89 - 4.95 min; DCF 8.32 - 8.40 $\min )$, resolution $(R=6)$ and total analysis time for diclofenac (DCF) separation and 4'-OH-DCF quantification was achieved with UPLC-DADUV, using a Supelco Ascentis Express C18 column $(75 \mathrm{~mm} \times 2.1 \mathrm{~mm}$ i.d. $\times 2.7 \mu \mathrm{m}$ particle size), gradient elution 3 using ultrapure water (Milli-Q-MiliREP) acidified with glacial acetic acid $(\mathrm{pH}=3.0)$, mobile phase $B$ and acetonitrile $(A C N)$ in mobile phase $A$ (acetonitrile $(A) /$ ultrapure acidified water $(B)$ - initial: $30(A) / 70(B)$; then 4 min: $50(A) / 50$ (B); then 6 min: $70(A) / 30(B)$; then 6-12 min: 70 (A)/ 30 (B); then 12.01: initial condition to re-equilibrate $-5 \mathrm{~min}$ ), with a flow rate at 0.25 $\mathrm{mL} / \mathrm{min}$, oven temperature $50{ }^{\circ} \mathrm{C}$ and injection volume of $1 \mu \mathrm{L}$, for a total analysis time of $17 \mathrm{~min}$ (condition 7, Table 1, Figure 2).

The maximum wavelength $(\lambda)$ obtained by the ultraviolet spectrum for 4'-OH-DCF was $264-267 \mathrm{~nm}$ and for DCF was $275-277 \mathrm{~nm}$. The tR for 4'-OH-DCF was registered at 4.89 $4.95 \mathrm{~min}$ and for DCF at $8.32-8.40 \mathrm{~min}$, demonstrating a complete separation of compounds and, therefore, the method selectivity.

The analytical curves obtained for 4'-OHDCF were done in the concentration range of 3.125 to $50.00 \mu \mathrm{g} / \mathrm{mL}$ in three different days. The analytical curves showed a positive linear correlation $>0.99$, therefore, showing excellent linearity $\left(r^{2}\right.$ day $1=0.9935 ; r^{2}$ day 2 $=0.9972 ; r^{2}$ day $\left.3=0.9903\right)$. Equation 1 was obtained by linear regression and used for quantification of 4'-OH-DCF, and was calculated by the mean and standard deviation of the linear and angular coefficients of the three equations obtained on the three different days:

Equation 1. Concentration $\mu \mathrm{g} / \mathrm{mL}$ of 4 '-OH$D C F=(A B S+1349 \pm 621) / 7181 \pm 294$ 
Table 1. Analytical parameters for separation of 4'-OH-DCF and DCF and quantification of 4'OH-DCF by HPLC-DAD-UV or UPLC-DAD-UV

\begin{tabular}{|c|c|c|}
\hline Condition & Mobile Phase (v/v) \% & Stationary Phase \\
\hline 1 & $\begin{array}{l}\text { acetonitrile }(50) / \\
\text { ultrapure acidified water }(50)\end{array}$ & $\begin{array}{c}\text { ACE C18 }(250 \mathrm{~mm} \times 4.6 \mathrm{~mm} \text { i.d. } \times 5 \mu \mathrm{m} \\
\text { particle size }) \text {, flow rate at } \\
1 \mathrm{~mL} / \mathrm{min}\end{array}$ \\
\hline 2 & $\begin{array}{c}\text { acetonitrile }(70) / \\
\text { ultrapure acidified water (30) }\end{array}$ & $\begin{array}{c}\text { ACE C18 }(250 \mathrm{~mm} \times 4.6 \mathrm{~mm} \text { i.d. } \times 5 \mu \mathrm{m} \\
\text { particle size }), \text { flow rate at } \\
1 \mathrm{~mL} / \mathrm{min}\end{array}$ \\
\hline 3 & $\begin{array}{c}\text { acetonitrile (75)/ } \\
\text { ultrapure acidified water (25) }\end{array}$ & $\begin{array}{c}\text { ACE C18 (250 } \mathrm{mm} \times 4.6 \mathrm{~mm} \text { i.d. } \times 5 \mu \mathrm{m} \\
\text { particle size }), \text { flow rate at } \\
1 \mathrm{~mL} / \mathrm{min}\end{array}$ \\
\hline 4 & $\begin{array}{c}\text { acetonitrile (78)/ } \\
\text { ultrapure acidified water (22) }\end{array}$ & $\begin{array}{c}\text { ACE C18 }(250 \mathrm{~mm} \times 4.6 \mathrm{~mm} \text { i.d. } \times 5 \mu \mathrm{m} \\
\text { particle size }), \text { flow rate at } \\
1 \mathrm{~mL} / \mathrm{min}\end{array}$ \\
\hline 5 & $\begin{array}{c}\text { acetonitrile (70)/ } \\
\text { ultrapure acidified water (25)/ } \\
\text { methanol (5) - gradient elution } 1\end{array}$ & $\begin{array}{c}\text { ACE C18 }(250 \mathrm{~mm} \times 4.6 \mathrm{~mm} \text { i.d. } \times 5 \mu \mathrm{m} \\
\text { particle size }), \text { flow rate at } \\
1 \mathrm{~mL} / \mathrm{min}\end{array}$ \\
\hline 6 & $\begin{array}{c}\text { kit BD Bioscience (acetonitrile/ } \\
\text { ultrapure acidified water (A) } \\
\text { methanol (B) - gradient elution } 2\end{array}$ & $\begin{array}{c}\text { ACE C18 }(250 \mathrm{~mm} \times 4.6 \text { i.d. } \mathrm{mm} \times 5 \mu \mathrm{m} \\
\text { particle size }), \text { flow rate at } \\
1 \mathrm{~mL} / \mathrm{min}\end{array}$ \\
\hline 7 & $\begin{array}{c}\text { acetonitrile/ } \\
\text { ultrapure acidified water - } \\
\text { gradient elution } 3\end{array}$ & $\begin{array}{c}\text { Supelco Ascentis Express } \mathrm{C} 18 \text { ( } 75 \mathrm{~mm} \times \\
2.1 \mathrm{~mm} \text { i.d. } x 2.7 \mu \mathrm{m} \text { particle size), flow } \\
\text { rate at } 0,25 \mathrm{~mL} / \mathrm{min}\end{array}$ \\
\hline
\end{tabular}

Oven temperature at $50{ }^{\circ} \mathrm{C}$, injection volumes from 5 to $20 \mu \mathrm{L}$. Gradient elution 1: acetonitrile (A)/ ultrapure acidified water (B)/ methanol (C) - initial: $70(A) / 25$ (B)/ 5 (C); then 4 min: $50(A) / 50(B)$; then $6 \mathrm{~min}: 70(A) / 30(B)$; then $6-12 \mathrm{~min}: 70(A) / 30(B)$; then 12.01: initial condition to re-equilibrate -5 min. Gradient elution 2: acetonitrile 30/ ultrapure acidified water $70(A) /$ methanol 100 (B) - initial: 80 (A)/ 20 (B); then 4 min: $50(A) / 50(B)$; then 6 min: $50(A) / 50(B)$; then $6-12$ min: $60(A) / 40(B)$; then 12.01: initial condition to reequilibrate $-5 \mathrm{~min}$. Gradient elution 3: acetonitrile $(A) /$ ultrapure acidified water $(B)$ - initial: $30(A) / 70(B)$; then $4 \mathrm{~min}: 50(A) / 50(B)$; then $6 \mathrm{~min}: 70(A) / 30(B)$; then $6-12 \mathrm{~min}: 70(A) / 30$ (B); then 12.01: initial condition to re-equilibrate $-5 \mathrm{~min}$ (total run time $=17 \mathrm{~min}$ ) 


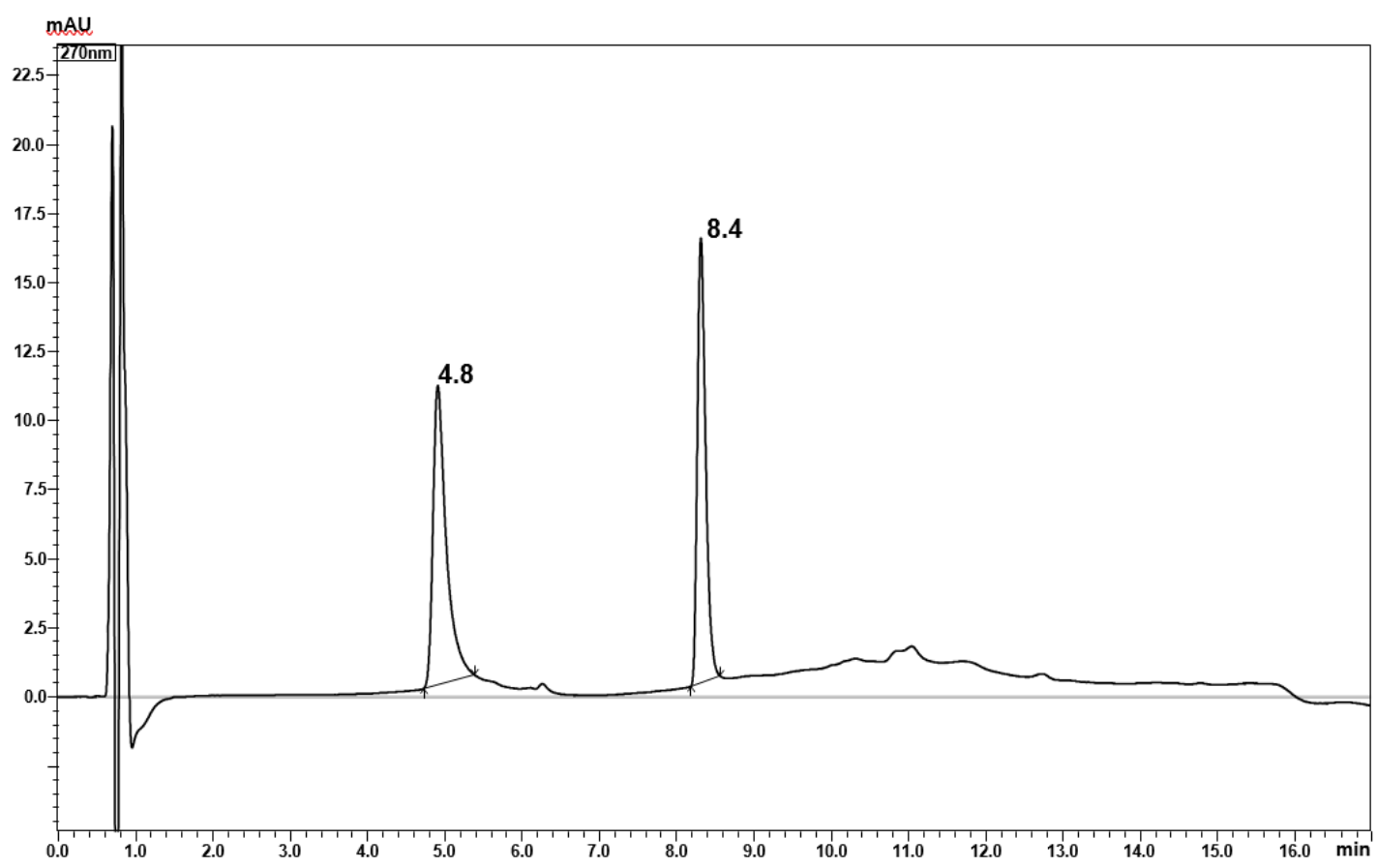

Figure 2. Chromatogram ( $270 \mathrm{~nm}$ ) of a mixture of $4^{\prime}-\mathrm{OH}-\mathrm{DCF}$ (water solution, $25 \mu \mathrm{g} / \mathrm{mL}$ ) and DCF (water solution, $25 \mu \mathrm{g} / \mathrm{mL}$ ): 4'-OH-DCF at retention time (tR) $4.8 \mathrm{~min}$ and DCF at tR $8.4 \mathrm{~min}$

The limit of detection (LOD) and the limit of quantification (LOQ) were determined by successive dilutions as 100 for 4 '-OH-DCF and $150 \mathrm{ng} / \mathrm{mL}$ for DCF.

Zi et al. ${ }^{22}$ used a Argilent Technologies $\mathrm{C} 18$ column $(250 \mathrm{~mm} \times 4.6 \mathrm{~mm}$ i.d. $\times 5 \mu \mathrm{m}$ particle size) with a mobile phase consisting of ultrapure water acidified with perchloric acid with $20 \%$ of acetonitrile and methanol (70:30 $\mathrm{v} / \mathrm{v})$, flow rate at $0.8 \mathrm{~mL} / \mathrm{min}$, oven temperature at $40^{\circ} \mathrm{C}$, and ultraviolet absorption spectrum at $280 \mathrm{~nm}$. The tR were recorded at 14.5 and $18.5 \mathrm{~min}$ for 4 '-OH-DCF and DCF, respectively. Another study conducted by Kimura et al. ${ }^{23}$ used a YMC-Pack ODS a-302 (150 mm x $4.6 \mathrm{~mm}$ i.d.) column, flow rate at $1.0 \mathrm{~mL} / \mathrm{min}$, oven temperature at $40{ }^{\circ} \mathrm{C}$, and a gradient elution using in the mobile phase (A) water, acetonitrile and formic acid (69:30:1) and in the mobile phase (B) methanol; with ultraviolet detection at 280 $\mathrm{nm}$ for DCF and a total analysis time of $20 \mathrm{~min}$. Our developed and validated method showed excellent selectivity, signal symmetry, resolution for DCF and 4'-OH-DCF separation in total analysis time of $17 \mathrm{~min}$ (shorter analysis time), linearity, non-use of methanol in the mobile phase and, mainly, lower mobile phase consumption (about $4 \mathrm{~mL}$ run). Thus, the method developed and validated in this study has clear advantages over 4'-OH-DCF analysis methods published in the literature.

\subsection{Diclofenac hydroxylation activity assay}

DCF hydroxylation activity assay was standardized by varying concentrations of non-induced female rat $\operatorname{LMF}(0.25,0.5,1$ and $2 \mathrm{mg} / \mathrm{mL})$ and reaction times $(10,20$ or 30 $\min$ ). As shown in Figure 3, good linearity of product accumulation over time was obtained for 1 or $2 \mathrm{mg} / \mathrm{mL}$ of protein and $20 \mathrm{~min}$ of reaction time. 


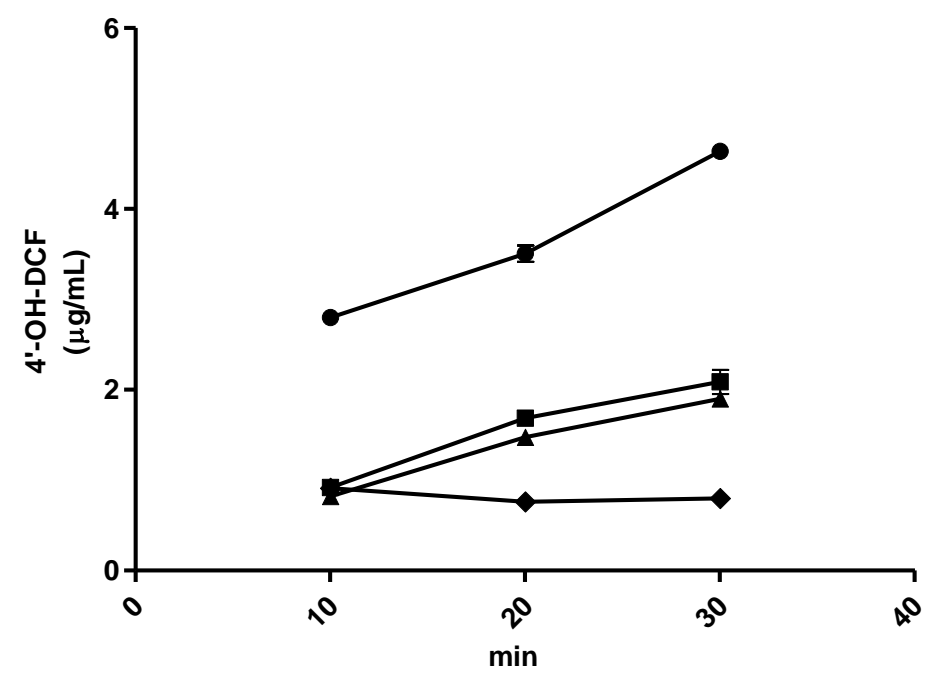

Figure 3. DCF hydroxylation assay: Accumulation of 4'-OH-DCF $(\mu \mathrm{g} / \mathrm{mL})$ over time $(10,20$ or 30

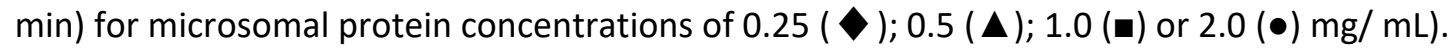
Liver microsomal fraction (LMF) was from untreated female Wistar rats

Figure 4 shows the relationship between the concentration of microsomal protein (1 or $2 \mathrm{mg} / \mathrm{mL}$ ) of non-induced and RIF-induced LMFs (from female Wistar rats) and the accumulation of 4 '-OH-DCF for a reaction time of $20 \mathrm{~min}$. As expected, results demonstrated that the highest concentration of microsomal protein yielded a greater amount of reaction product (4'-OH-DCF). Moreover, results also confirmed that for identical microsomal protein concentrations and reaction time (20 min), RIF-induced rat LMF yielded an amount of 4'-OH-DCF greater than the amount formed by untreated (non-induced) rat LMF. In other words, RIF treatment did in fact increase the activity (or relative abundance) of CYP enzymes that catalyze the conversion of DCF into its primary oxidation metabolite $\left(4^{\prime}-\mathrm{OH}-\right.$ DCF) in the rat liver.

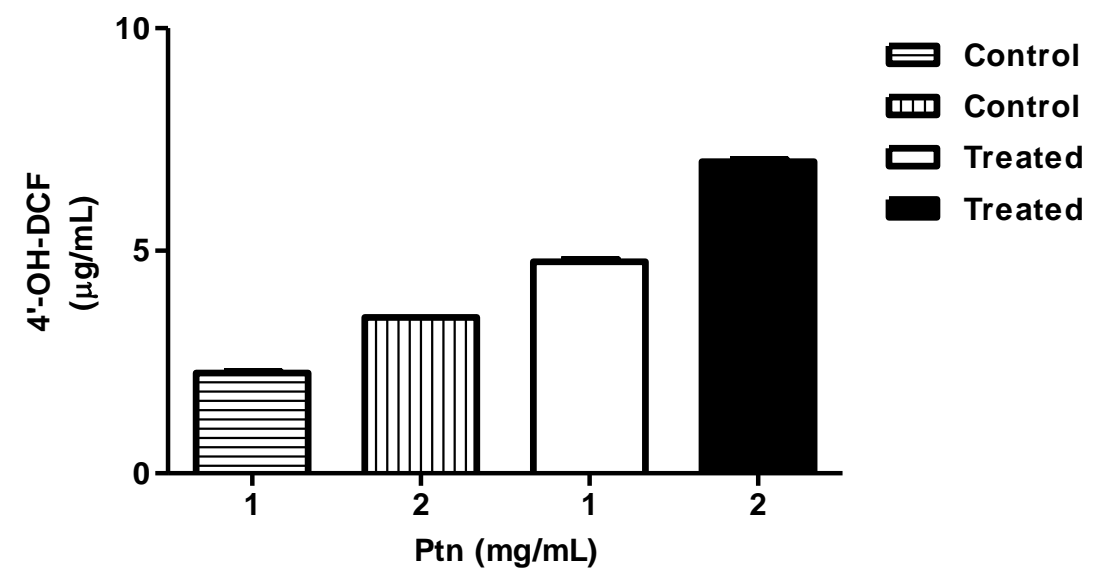

Figure 4. DCF hydroxylation assay. Formation of reaction product (4'-OH-DCF; $\mu \mathrm{g} / \mathrm{mL}$ ) as function of concentration of microsomal protein ( 1 and $2 \mathrm{mg} / \mathrm{mL}$ ) for both non-induced (Control) and RIF-induced liver microsomal fractions (Treated) from female Wistar rats.

Reaction time was $20 \mathrm{~min}$ 
Based on the foregoing results, DCF hydroxylation assay to test PCs was conducted with RIF-induced rat LMF with microsomal protein concentration and reaction duration of $1 \mathrm{mg} / \mathrm{mL}$ and $20 \mathrm{~min}$, respectively.

\subsection{Inhibition of DCF hydroxylation (CYP2C) by phenolic acids and flavonoids}

The four phenolic acids (caffeic 1, ferulic $\mathbf{2}$, $p$-coumaric $\mathbf{3}$ and vanillic $\mathbf{4}$, Figure 5 ), tested at a concentration as high as $100 \mu \mathrm{M}$ in the assay medium, did not decrease DCF hydroxylation activity whereas fluconazole $(100 \mu \mathrm{M})$, a putative CYP2C9 inhibiting drug ${ }^{21}$, caused a nearly $24 \%$ reduction in the hydroxylation activity (Table 2, Figure 6 ). The flavonoids hesperidin (5) and quercetin (6), also tested at $100 \mu \mathrm{M}$, caused only a slight to moderate (15$21 \%)$ inhibition of DCF-hydroxylation activity. Rutin $(100 \mu \mathrm{M})$, or quercetin 3-O-rutinoside (7) (Figure 7), decreased by approximately 21 $\%$ the DCF hydroxylation activity while fluconazole $100 \mu \mathrm{M}$ reduced it by $27 \%$ or so (Table 3, Figure 8).

Martignoni et al..$^{21}$ reported that rat tissues express several CYP2C family isoforms, including CYP2C6, CYP2C7, CYP2C11, CYP2C12, CYP2C13 and CYP2C22. The expression of a particular CYP2C isoform, however, varies with rat gender and age, being generally higher in adult animals. CYP2C12 is highly expressed in the liver of female adult rats, whereas CYP2C11 is the predominant isoform in male rats, comprising up to $50 \%$ of the total CYP content of the hepatic tissue. Humans express CYP2C8, CYP2C9 and CYP2C19 isoforms the expression of which is inducible by ligands known to activate PXR nuclear receptor, such as rifampicin and dexamethasone, or Constitutive Androstane Receptor (CAR), a nuclear factor typically activated by phenobarbital. ${ }^{24}$ Therefore, it is fair to think that treatment with rifampicin (RIF) enhanced expression of $\mathrm{CYP} 2 \mathrm{C} 12$ in the female rat liver. RIF, however, is also a classical inducer of CYP3A enzymes. ${ }^{25}$

Kimura et al. ${ }^{23}$ tested 60 polyphenols (at $100 \mu \mathrm{M})$ for inhibitory effects on the $6 \beta$ hydroxylation of testosterone by recombinant human CYP3A4 (rhCYP3A4) and hydroxylation of diclofenac (DCF) by recombinant human CYP2C9 (rhCYP2C9). The authors found that several coumarins, flavones and flavonoids strongly inhibited rhCYP3A4 and rhCYP2C9 $(>80 \%)$ whereas inhibitory effects of flavanones, chalcones and isoflavones on these enzymes are weaker $(<50 \%){ }^{23}$ According to Kimura et al., glycosylated flavonoids are weaker inhibitors of both enzymes ( $<55 \%)$, while anthocyanidins and monoterpenes have a weak effect on rhCYP2C9. ${ }^{23}$

Table 2. Activities (Mean $\pm \mathrm{SE}$ ) of diclofenac hydroxylation (4'-OH-DCF; $\mathrm{ng} / \mathrm{mg} \mathrm{ptn} / \mathrm{min}$ ) in the absence (control) and in the presence $(100 \mu \mathrm{M})$ of caffeic, ferulic, $p$-coumaric and vanillic acids, as well as in the presence of the positive control fluconazole $(100 \mu \mathrm{M})$. Percentage of inhibition (\%) is shown in brackets

\begin{tabular}{cllccc}
\hline control & caffeic & ferulic & p-cumaric & vanilic & fluconazole \\
\cline { 2 - 5 } & \multicolumn{5}{c}{ Phenolic acid } \\
\hline $12.4 \pm 0.3$ & $12.3 \pm 0.3$ & $11.6 \pm 0.2$ & $12.7 \pm 0.2$ & $11.6 \pm 0.3$ & $9.4 \pm 0.2$ \\
$(100 \%)$ & $(0.8 \%)$ & $(0.6 \%)$ & $(0 \%)$ & $(0.6 \%)$ & $(24.2 \%)$ \\
& & & & \\
\hline
\end{tabular}


<smiles>O=C(O)/C=C/c1ccc(O)c(O)c1</smiles>

(1)<smiles>COc1cc(/C=C/C(=O)O)ccc1O</smiles>

(2)<smiles>O=C(O)/C=C/c1ccc(O)cc1</smiles>

(3)<smiles>O=C(O)c1ccc(O)cc1</smiles>

(4)

Figure 5. phenolic acids structures: $\mathbf{1}$ - caffeic; $\mathbf{2}$ - ferulic; $\mathbf{3}$ - $p$-coumaric and $\mathbf{4}$ - vanillic

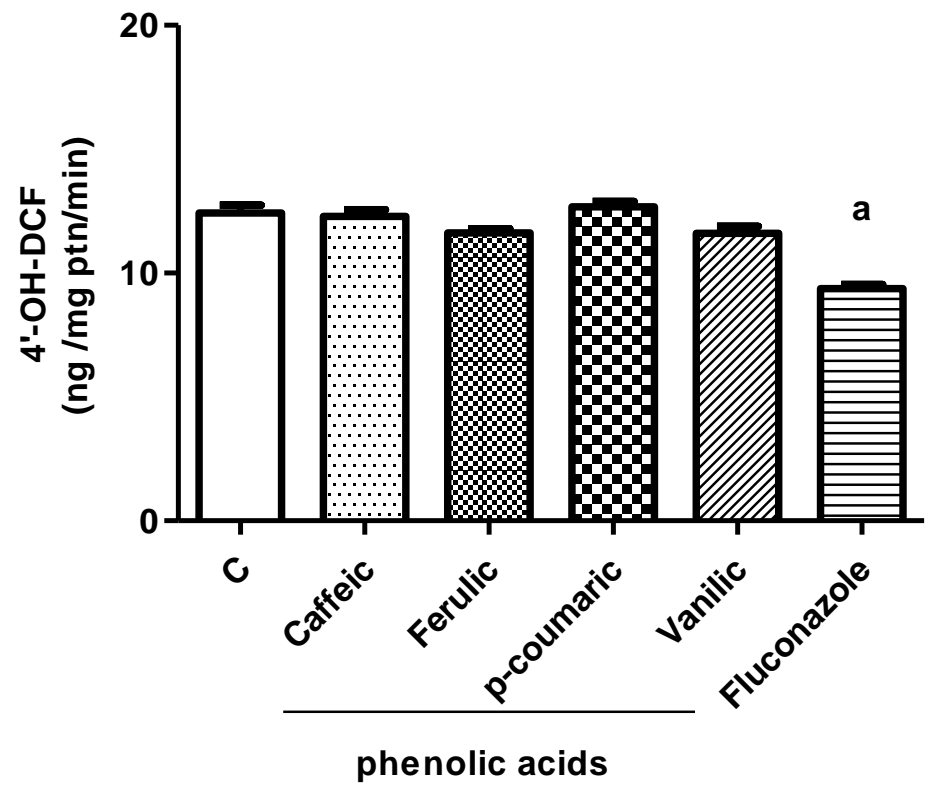

Figure 6. Absence of inhibitory effects of phenolic acids (caffeic, ferulic, $p$-coumaric and vanillic acids) on diclofenac (DCF) hydroxylation activity (4'-OH-DCF $\mathrm{ng} / \mathrm{mg}$ protein/ min). Rifampicininduced liver microsomes from female Wistar rats. Histogram bar heights are Mean \pm SEM. ANOVA followed by the Bonferroni's multiple comparison test: $\mathrm{a}: \neq$ from control $(p<0.05)$

Table 3. Activities (Mean $\pm \mathrm{SE}$ ) of diclofenac hydroxylation (4'-OH-DCF $\mathrm{ng} / \mathrm{mg} \mathrm{ptn} / \mathrm{min}$ ) in the absence (control) and in the presence $(100 \mu \mathrm{M})$ of the flavonoids hesperidin, quercetin and rutin, as well as in the presence of the positive control fluconazole $(100 \mu \mathrm{M})$. Percentage of inhibition (\%) is shown in brackets

\begin{tabular}{ccccc}
\hline \multirow{2}{*}{ control } & hesperidin & quercetin & rutin & \multirow{2}{*}{ fluconazole } \\
& \multicolumn{5}{c}{ flavonoid } \\
\cline { 2 - 4 } & $10.7 \pm 0.3$ & $11.0 \pm 0.07$ & $10.3 \pm 0.07$ & $9.0 \pm 0.2$ \\
$(13.0 \pm 0.4$ & $(15 \%)$ & $(18 \%)$ & $(21 \%)$ & $(27 \%)$ \\
\hline
\end{tabular}


<smiles>[R]c1cc(O)c2c(c1)O[C@@H](c1ccc(O)c(O)c1)CC2=O</smiles>

(5) $\mathrm{R}_{1}=$ O--Rhamnosyl-glucosyl
(6)<smiles>[R7]c1c(-c2ccc(O)c(O)c2)oc2cc(O)cc(O)c2c1=O</smiles>

(7) $\mathrm{R}_{1}=$ O-Glucosyl-rhamnosyl

Figure 7. Flavonoids structures: $\mathbf{5}$ - hesperidin; $\mathbf{6}$ - quercetin; $\mathbf{7}$ - rutin

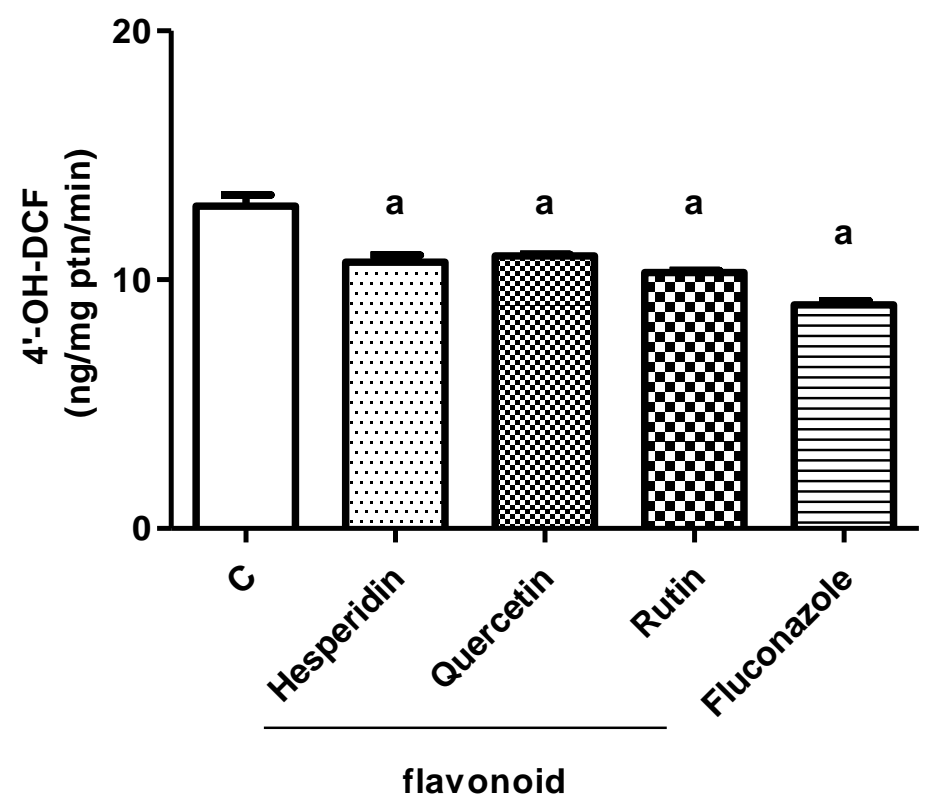

Figure 8. Inhibition of diclofenac (DCF) hydroxylation activity (4'-OH-DCF ng/ mg protein/ min) by flavonoids hesperidin, quercetin and rutin. Rifampicin-induced liver microsomes from female Wistar rats. Histogram bar heights are Mean \pm SEM. ANOVA followed by the Bonferroni's multiple comparison test: a: $\neq$ from control $(p<0.05)$

Our results regarding the inhibition of DCF hydroxylation by rutin in the rat LMF (ca $21 \%$ inhibition) were similar to those obtained by Kimura et $a .^{23}$ for the inhibition of rhCYP2C9 by this glycosylated flavonoid (ca $25 \%$ inhibition). Quercetin $100 \mu \mathrm{M}$, however, caused a $100 \%$ inhibition of DCF hydroxylation catalyzed by rhCYP2C9 and a weak inhibition of DCF hydroxylation mediated by the RIF-induced rat LMF. The reasons for this apparent discrepancy between inhibitory effects of quercetin on rat LMF (a complex mixture of CYP2C12 and many other CYP forms) and on isolated human CYP2C9 enzyme are not entirely clear. Quercetin seemed to be an inhibitor of (isolated) human CYP2C9 with an $\mathrm{IC}_{50}$ as low as
$26.1 \mu \mathrm{M} .{ }^{23}$ Further studies are necessary to clarify this question, including investigation of the inhibitory effects of quercetin on the hydroxylation of DCF by human liver microsomal fractions and a clarification of which rat liver CYP forms are substrates for quercetin and DCF.

\section{Conclusion}

A new UPLC-DAD-UV method to quantify the hydroxylation product of diclofenac (4'hydroxydiclofenac) was developed and validated. This new chromatographic method compares favorably with previously published 
methods in various aspects such as to use a methanol free mobile phase, to be less timeconsuming and to require the use of smaller volumes of solvent. Moreover, the analytical method proved to be suitable to quantify the product of the DCF hydroxylation (diclofenac conversion to 4 '-hydroxydiclofenac) in the liver microsomal fraction.

Overall, results showed that the tested PCs, at a concentration as high as $100 \mu \mathrm{M}$, did not inhibit at all or have only a weak to modest inhibitory effect on the DCF hydroxylation by rat liver enzymes. These findings indicated that, at levels found in the human diet, caffeic, ferulic, $p$-coumaric and vanillic acids, as well as hesperidin and quercetin do not interfere with the CYP2C-mediated clearance of drugs and xenobiotics in the rat. The modest inhibition of DCF hydroxylation by quercetin, hesperidin and rutin $(100 \mu \mathrm{M})$ suggests that at concentrations commonly found in food and medicinal plants these flavonoids are unlikely to alter the pharmacokinetics of DCF and related drugs in rats.

\section{Acknowledgements}

This study was partially funded by a grant from FAPERJ (E-26/110.676/2012). he experiment reported here. is part of the first author's (Carlos H. Ramos) MSci dissertation presented at the National School of Public Health - FIOCRUZ.

\section{References}

${ }^{1}$ Virgili, F.; Pagana, G.; Bourne, L.; Rimbach, G.; Natella, F.; Rice-Evans, C.; Packer, L. Ferulic acid excretion as a marker of consumption of a French maritime pine (Pinus maritima) bark extract. Free Radical Biology and Medicine 2000, 28, 1249. [CrossRef] [PubMed]

${ }^{2}$ Lin, D.; Xiao, M.; Zhao, J.; Li, Z.; Xing, B.; Li, X.; Kong, M.; Li, L.; Zhang, Q.; Liu, Y.; Chen, H.; Qin, W.; Wu, H.; Chen, S. An Overview of Plant
Phenolic Compounds and Their Importance in Human Nutrition and Management of Type 2 Diabetes. Molecules 2016, 21, 1374. [CrossRef] [PubMed]

${ }^{3}$ Anantharaju, P. G.; Gowda, P. C.; Vimalambike, M. G.; Madhunapantula, S. V. An overview on the role of dietary phenolics for the treatment of cancers. Nutrition Journal 2016, 15, 99. [CrossRef] [PubMed]

${ }^{4}$ Ververidis F, Trantas E, Douglas C, Vollmer G, Kretzschmar G, Panopoulos N. Biotechnology of flavonoids and other phenylpropanoidderived natural products. Part I: Chemical diversity, impacts on plant biology and human health. Biotechnology Journal: Healthcare Nutrition Technology 2007, 2, 1214. [CrossRef] [PubMed]

${ }^{5}$ Panche, A. N.; Diwan, A. D.; Chandra, S. R. Flavonoids: an overview. Journal of Nutritional Science 2016, 5, 47. [CrossRef] [PubMed]

${ }^{6}$ Spencer, J. P. Flavonoids: modulators of brain function? British Journal of Nutrition 2008, 99, 60. [CrossRef] [PubMed]

${ }^{7}$ Souza, G.R.; De-Oliveira, A. C. A. X.; Soares, V.; Chagas, L. F.; Barbi, N. S.; Paumgartten, F. J. R.; Silva, A. J. R. Chemical profile, liver protective effects and analgesic properties of a Solanum paniculatum leaf extract. Biomedicine \& Pharmacotherapy 2019, 110, 129. [CrossRef] [PubMed]

${ }^{8}$ Ahangarpour, A.; Sayahi, M.; Sayahi, M. The antidiabetic and antioxidant properties of some phenolic phytochemicals: A review study. Diabetes \& Metabolic Syndrome: Clinical Research \& Reviews 2019, 13, 854. [CrossRef]

${ }^{9}$ Knekt, P.; Järvinen, R.; Seppänen, R.; Hellövaara, M., Teppo, L.; Pukkala, E.; Aromaa, A. Dietary flavonoids and the risk of lung cancer and other malignant neoplasms. American Journal of Epidemiology 1997, 146, 223. [CrossRef] [PubMed]

${ }^{10}$ Sak, K. Intake of Individual Flavonoids and Risk of Carcinogenesis: overview of epidemiological evidence. Nutrition and Cancer 2017, 69, 1119. [CrossRef] [PubMed] 
${ }^{11}$ Sak, K. Current epidemiological knowledge about the role of flavonoids in prostate carcinogenesis. Experimental Oncology 2017, 39, 98. [CrossRef] [PubMed]

${ }^{12} \mathrm{Xu}$, M.; Chen, Y. M.; Huang, J.; Fang, Y. J.; Huang, W. Q.; Yan, B.; Lu, M.S.; Pan Z. Z.; Zhang, C. X. Flavonoid intake from vegetables and fruits is inversely associated with colorectal cancer risk: a case-control study in China. British Journal of Nutrition 2016, 116, 1275. [CrossRef] [PubMed]

${ }^{13}$ Wang, X.; Ouyang, Y. Y.; Liu, J.; Zhao, G. Flavonoid intake and risk of CVD: a systematic review and meta-analysis of prospective cohort studies. British Journal of Nutrition 2014, 111, 1. [CrossRef] [PubMed]

${ }^{14}$ Genser, D. Food and drug interaction: consequences for the nutrition/health status. Annals of Nutrition and Metabolism 2008, 52, 29. [CrossRef] [PubMed]

${ }^{15}$ Zhou, S.; Gao, Y.; Jiang, W.; Huang, M.; Xu, A.; Paxton, J. W. Interactions of herbs with cytochrome P450. Drug Metabolism Reviews 2003, 35, 35. [CrossRef] [PubMed]

${ }^{16}$ Kumar, V.; Rock, D. A.; Warren, C. J.; Tracy, T. S.; Wahlstrom, J. L. Enzyme source effects on CYP2C9 kinetics and inhibition. Drug Metabolism and Disposition 2006, 34, 11, 1903. [CrossRef] [PubMed]

${ }^{17}$ Kumar, V.; Wahlstrom, J. L.; Rock, D. A.; Warren, C. J.; Gorman, L. A.; Tracy, T. S. CYP2C9 inhibition: impact of probe selection and pharmacogenetics on in vitro inhibition profiles. Drug Metabolism and Disposition 2006, 34, 1966. [CrossRef] [PubMed]

${ }^{18}$ Oesch, F.; Arand, M.; Benedetti, M. S.; Castelli, M. G.; Dostert, P. Inducing properties of rifampicin and rifabutin for selected enzyme activities of the cytochrome P-450 and UDP-glucuronosyltransferase superfamilies in female rat liver. Journal of
Antimicrobial Chemotherapy 1996, 37, 6, 1111. [CrossRef] [PubMed]

${ }^{19}$ Bradford, M. M. A rapid and sensitive method for the quantitation of microgram quantities of protein utilizing the principle of protein-dye binding. Analytical Biochemistry 1976, 72, 248. [CrossRef] [PubMed]

${ }^{20}$ De-Oliveira, A. C.; Ribeiro-Pinto, L. F., Paumgartten, J. R. In vitro inhibition of CYP2B1 monooxygenase by beta-myrcene and other monoterpenoid compounds. Toxicology Letters 1997, 92, 39. [CrossRef] [PubMed]

${ }^{21}$ Martignoni, M.; Groothuis, G. M.; Kanter, R. Species differences between mouse, rat, dog, monkey and human CYP-mediated drug metabolism, inhibition and induction. Expert Opinion on Drug Metabolism \& Toxicology 2006, 2, 875. [CrossRef] [PubMed]

22 Zi, J.; Liu, D.; Ma, P.; Huang, H.; Zhu, J.; Wei, D.; Yang, J.; Chen, C. Effects of CYP2C9*3 and CYP2C9*13 on Diclofenac Metabolism and Inhibition-based Drug-Drug Interactions. Drug Metabolism and Pharmacokinetics 2010, 25, 343. [CrossRef] [PubMed]

${ }^{23}$ Kimura, Y.; Ito, H.; Ohnishi, R.; Hatano, T. Inhibitory effects of polyphenols on human cytochrome P450 3A4 and 2C9 activity. Food and Chemical Toxicology 2010, 48, 429. [CrossRef] [PubMed]

${ }^{24}$ Daly, A. K.; Rettie, A. E.; Fowler, D. M.; Miners, J. O. Pharmacogenomics of CYP2C9: Functional and Clinical Considerations. Journal of Personalized Medicine 2017, 28, 1. [CrossRef] [PubMed]

${ }^{25}$ Srinivas, N. R. Pharmacokinetic Interaction of Rifampicin with Oral Versus Intravenous Anticancer Drugs: Challenges, Dilemmas and Paradoxical Effects Due to Multiple Mechanisms. Drugs in R\&D 2016, 16, 141. [CrossRef] [PubMed] 